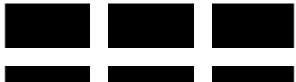 \\ ThE WILliam DAVIDSON InSTITUTE AT THE UNIVERSITY OF MICHIGAN BUSINESS SCHOOL
}

\section{On the long-run determinants of real exchange rates for developing countries : Evidence from Africa, Latin America and Asia}

\author{
By: Imed Drine and Christophe Rault
}

William Davidson Working Paper Number 571

May 2003 


\title{
On the long-run determinants of real exchange rates for developing countries : Evidence from Africa, Latin America and Asia
}

\author{
Imed DRINE®(EUREQua, Sorbonne University), \\ Christophe RAULTY(EPEE, Evry University and EUREQua)
}

M ay 2003

\begin{abstract}
A bstract
The main goal of this paper is to tackle the empirical issues of the real exchange rate litterature by applying recently developed panel cointegration techniques to a structural long-run real exchange rate equation. We consider here a sample of 45 devel oping countries, divided into three groups according to geographical criteria: A frica, L atin A merica and A sia. Our investigations con..rm that having a reference to assess the degree of distortion of real exchange rate is not as simple as it can be thought with the PPP concept. The real exchange rate is ex ectively at the centre of an economic spiral and its value dep ends on the economic speci..cities of each country. In other words, we don't have a ..xed and general norm but, for each economy, the real exchange rate trajectory depends on its development level, on the way economic policy is conducted, and on its position on the international market. C15.

K eywords : Real exchange rate, Developing country, E31, F 0, F 31,

J E L Classi..cation : E 31, F0, F 31, C15.
\end{abstract}

\footnotetext{
«Paris I, Maison des Sciences de l'E conomie, 106-112 bd. de L'Hôpital, 75647 Paris Cedex 13, France. E-mail :drine@univ-paris1.fr

YUniversity of Evry-Val d'Essonne, Département d'économie, Boulevard François M itterrand, 91025 É vry Cedex, France. E-mail : chrault@hotmail.com, web-site : http:// www.multimania.com/chrault/ index.html
} 


\section{Introduction}

The relationship between real exchange rate and economic development is certainly an important issue, both from the positive (descriptive) and normative (policy prescription) perspectives. In recent years, policy discussions have included increasing references to real exchange rate stability and correct exchange rate alignment as crucial elements to improve economic performance in emergent countries. Real exchange rate misalignment axects economic activity in developing countries mainly due to the dependence on imported capital goods and specialization in commodity exports. Accessibility to world ..nancial markets which helps to smooth consumption by ..nancing trade imbalance, also plays an important role. Evidence from developing countries is often quoted to support the view that the link between real exchange rate misalignment and economic performance is strong. Cottani and al (1990) argued that in many emergent countries, persistently misaligned exchange rate harmed the development of agriculture, reducing domestic food supply. B esides, a number of researchers have also pointed out the importance of understanding the main determinants of real exchange rate.

Edwards (1989) for instance has developed a theoretical model of real exchange rate and has provided an estimation of its equilibrium value for a panel of developing countries using conventional cointegration tests on time series data (cf. J ohansen, 1988). According to this estimation, only real variables axect real the exchange rate in the long-run, but in the short-run both real and nominal variables contribute to its variations. More precisely, the most important variables axecting the real exchange rate equilibrium level are the terms of trade, the level and the composition of public spending, capital movements, the control of exchange and the movements of goods, technical progress, and capital accumulation.

Following E dwards's pioneering works, ap plied studies using J ohansen's coin- 
tegration tests to estimate equilibrium exchange rates have increased these last past years, both for developed countries (Stein, 1994; Faruqee, 1995; A glietta and al.,1997, MacDonald, 1997), and for developing countries (cf. for example Ghura and Grennes, 1993; Elbadawi and Soto, 1995; Aron and al, 1997). In these studies the main long-run determinants of the real exchange rate are the terms of trade, the openness degree of the economy, capital łows, and the nominal exchange rate.

The aim of this paper is to apply recent advances in the econometrics of non-stationary dynamic panel methods to examine the robustness of the conclusions obtained with conventional time series cointegration techniques, concerning the main long-run determinants of the real exchange rate. We consider a sample of 45 developing countries, divided into three groups according to geographical criteria: Africa (21 countries: Algeria, Benin, Burkina Faso, B urundi, Cameroon, Congo, the democratic Republic of Congo, Ivory Coast, Egypt, Ethiopia, Gabon, Gambia, Ghana, Guinea B issau, Kenya, Mali, M orocco, M ozambique, Niger, Senegal, Tunisia), Latin A merica (17 count ries: A rgentina, B olivia, Brazil, Chile, Colombia, Costa Rica,the Dominican Republic, Ecuador, Guatemala, Honduras, M exico, Nicaragua, Panama, Peru, Paraguay, Uruguay, Venezuela) and A sia ( 7 countries: Bangladesh, Indonesia, South K orea, India, M alaysia, the P hilippines, Thailand). The point is to go beyond the teachings of the Balassa-Samuelson's theory (cf. in particular Drine and R ault, 2003a and É gert, D rine, L ommatzsch and Rault, 2003b for these countries) and to determine if other factors, such as the demand factors, the economic policy or the capital movements, also have an infuence on the equilibrium real exchange rate level determination. Our econometric methodology rests upon the panel data integration tests proposed by Im, Pesaran and Shin (1997) and on the panel data cointegration tests recently developed by Pedroni (1997, 1999, 2000). There does not exist to our best knowledge comparable studies using these new econometric techniques to investigate the main macroeconomic variables inłuencing the real exchange rate in the long run in developing countries.

The remainder of the paper is organized as follows. In the second section 
we present a simple theor etical model of real exchange rate determination, and carefully analyze the expected theoretical exects of the main real exchange rate determinants on the long-run real exchange rate level. In the third section we expose the panel data unit root tests and panel cointegration methodology that will be used in the empirical application. In the fourth section we report and comment on our econometric results for a panel of 45 developing countries. A ..nal section reviews the main ..ndings. We ..nd in particular, that besides the $B$ alassa-Samuelson exect, other macroeconomic variables, such as the terms of trade, public spending, investment, commercial policy, have a signi..cant in $¥ u$ ence on the real exchange rate level in the long-run.

\section{Real equilibrium exchange rate determinants}

Following Edwards (1989), we estimate the equilibrium real exchange rate value using a theoretical model, where the simultaneous equilibrium of the current balance and the tradable good market is realized (see E mre et al, 2000). In the model short-run and long-run real exchange rate determinants are dixerent, but only real variables axect the equilibrium value of the real exchange rate. However, in the short run, both nominal and real variables contribute to the real exchange rate variations.

\subsection{The model}

We consider a small, open economy model with three goods - exportable $(X)$, importable (M) and non-tradable ( $N$ ). T he economy involves consumers. The country produces non-tradable and exportable goods and consumes nontradable and importable goods.

The country has a foating exchange rate system, with $E$ denoting the nom $\mathrm{i}-$ nal exchange rate in all transactions. Let $P_{x}$ and $P_{N}$ be the prices of importable and non-tradable goods respectively. The world price of exportable goods is normalized to unity $\left(P_{X}^{x}=1\right)$, so the domestic price of exportable goods is $\mathrm{P}_{\mathrm{X}}=\mathrm{EP}_{\mathrm{X}}^{\mathrm{x}}=\mathrm{E}$. The world price of importable goods is denoted by $\mathrm{P}_{\mathrm{M}}^{\mathrm{x}}$ : 
We de.ne $e_{M}$ and $e_{x}$ as the domestic relative prices of importable and exportable goods with respect to non-tradable ones, respectively :

$$
\Theta_{M}=\frac{P_{M}}{P_{N}}
$$

and

$$
e_{x}=\frac{E}{P_{N}}
$$

Then the relative price of importable goods with respect to non-tradable ones is:

$$
\mathrm{e}_{\mathrm{M}}^{\mathrm{\alpha}}=\frac{\mathrm{EP}_{\mathrm{M}}^{\mathrm{\alpha}}}{\mathrm{P}_{\mathrm{N}}}
$$

The country imposes tarixs on imports so that

$$
P_{M}=E P_{M}^{\alpha}+i
$$

, where $i$ is the tarix rate.

The total output, $Q$, in the country is

$$
Q=Q_{X}\left(e_{X}\right)+Q_{N}\left(e_{X}\right)
$$

, where $\mathrm{Q}_{\mathrm{X}}^{0}>0$ and $\mathrm{Q}_{\mathrm{N}}^{0}<0$ :

The private consumption, $C$, is given by

$$
C=C_{M}\left(e_{M}\right)+C_{N}\left(e_{M}\right)
$$

, where $C_{M}$ and $C_{N}$ are consumption on importable and non-tradable goods respectively, and $C_{M}^{0}<0 ; C_{N}^{0}>0$ :

We de. ne the real exchange rate as the relative price of tradable goods to non-tradable ones and denote it by e:

$$
e=\otimes_{M}+(1 ; \otimes) e_{x}=\frac{E\left(\otimes_{M}^{a}+(1 ; ®)\right)+i}{P_{N}}
$$

with $\circledast 2(0 ; 1)$ 
C apital is perfect ly mobile. T he net foreign assets of the country are den oted by $A$. The country invests its net foreign assets at the international real interest rate $r^{x}$. The current account of the country in a given year is the sum of the net inter est earnings on the net foreign assets and the trade surplus in foreign currency as the dixerence between the output of exportable goods and the total consumption of importable goods :

$$
C A=r^{\alpha} A+Q_{x}\left(e_{x}\right) i P_{M}^{\alpha} C_{M}\left(e_{M}\right)
$$

The change in the foreign cur rency reserves, $R$, of the country is then given by

$$
\dot{R}=\mathrm{CA}+\mathrm{KI}
$$

, where $\mathrm{KI}$ is the net capital in $\ddagger$ ows.

In the short and medium run, there can be departures from $\dot{R}=0$, so that the country may gain or lose reserves. Current account is sustainable if the current account de..cit plus the net capital inłows in the long run sum up to zero so that the o cial reserves of the country do not change.

We then say that the economy is in external equilibrium if the sum of the current account balance and the capital account balance equal to zero, i.e.

$$
\begin{gathered}
r^{x} A+Q_{X}\left(e_{X}\right) ; P_{M}^{a} C_{M}\left(e_{M}\right)+K I=0 \\
C_{N}\left(e_{M}\right)+G_{N}=Q_{N}\left(e_{X}\right)
\end{gathered}
$$

where $G_{N}$ denotes public spending in non-tradable goods.

A real exchange rate is then said to be in equilibrium if it leads to external and internal equilibria simultaneously. From (10) and (11) it is possible to express the equilibrium exchange rate, $e^{\alpha}$, as a function of $P_{M}^{\alpha} ; \mathcal{L} ; r^{\natural} ; A ; K I$ and $G_{N}$, i.e.

$$
e^{a}=e^{a}\left(P P_{M}^{a} ; i ; r^{a} ; A ; K I ; G_{N}\right)
$$


The real exchange rate equilibrium level is thus a function of the terms of trade, of commercial policy, of the foreign interest rate, of foreign capital $\ddagger$ ows, and of public spending. Therefore, in addition to the Balassa-Samuelson exect, there exists other determinants which can have a permanent exect on real exchange rates.

This model can be completed by speci..cation enrichments, which introduce new variables of the real exchange rate level. A mong these determinants we ..nd for instance investment rate and technical progress. Baxes and al (1999) present an extension of this model taking the rationing of foreign credits, the domestic price variations of tradable goods and the rigidity of wages and prices into account. As for Edwards, he identi..es as determinants of the real exchange rate equilibrium those that depend on economic policy such as the composition of public spending, the limitation of imports, the taxes on exports, the control of exchange and capital movements and the other types of restrictions imposed by the State.

\subsection{A nalysis of the relation between the real exchange rate and its fundamentals}

\subsubsection{A terms-of-trade variation}

We de..ne terms of trade as the relative price of exports with respect to imports and denoted by

$$
\mathrm{TOT}=1=P_{M}^{\mathrm{a}}
$$

Here we assume that the nominal exchange rate $E$ is $\ddagger$ exible but the prices of non-tradable goods, $\mathrm{PN}$, is ..xed. A $n$ improvement in the terms of trade (due to a decrease in $P_{M}^{a}$ ) leads to an increase in the nominal exchange rate $E$, and hence the relative prices of exportable goods with respect to non-tradable ones, ( $\left.e_{x}\right)$ : T hen, the relative prices of importable goods with respect to non-tradable ones, $\Theta_{n}$, must decrease to restore the internal equilibrium. The consumption 
of non-tradable goods and the output of non-tradable ones both decrease, and the internal sector remains in equilibrium, though at a higher nominal exchange rate. Meanwhile, the output of the exportable goods increases due to depreciation in the value of the domestic currency. The consumption of importable goods increases due to a fall in import prices. Moreover, the private expenditure on importable goods also rises, and hence the external sector remains in equilibrium.

From (7), one can write

Since $i$ is constant. From (10) one can also write

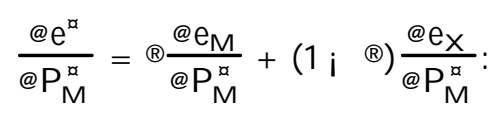

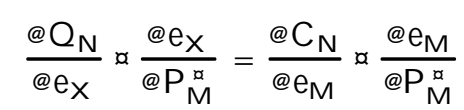

So, combining the last two equations we obtain

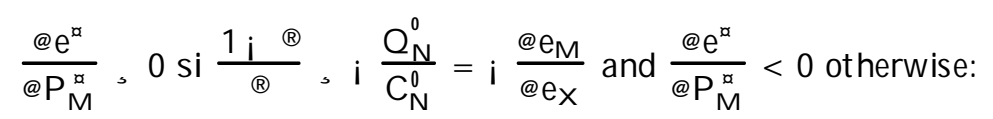

The impact of the terms of trade on the real exchange rate is theoretically ambiguous (cf. notably Edwards, 1989; Elbadawi and Soto, 1995; as well as B axes and al, 1999). A terms of trade improvement generates a direct income exect, which leads to an increase of the non-tradable goods demand, and an indirect substitution exect which induces a variation of the oxer and demand of the non-tradable goods. Consequently, according to the relative magnitude of these two exects there will be either an appreciation or a depreciation of the real exchange rate.

To illustrate the income exect let us assume an improvement of the terms of trade following for example a price increase of the exported goods and assume that the prices of imported goods remain unchanged. The increase of domestic income which results from it, will lead to an increase of the non-tradable and imported goods demand. As the price of imported goods is constant, the demand increase entails an increase of non-tradable goods price and then a real 
exchange rate appreciation. A terms of trade deterioration entails, on the other hand, a decrease of income and demand and consequently a real exchange rate depreciation.

A real exchange rate improvement can have an opposite exect on the real exchange rate if the indirect substitution exect is higher than the income effect. For instance, a terms of trade improvement provides currency resources necessary to produce more non-tradable goods. Given the strong dependence of developing countries with respect to imports with intermediate goods, an increase of available resources permits to produce more and then to lower the price of non-tradable goods. Thus, a terms of trade improvement leads to a real exchange rate depreciation and vice versa. Elbadawi and Soto (1995) studied 7 developing countries and found that for three of them a terms of trade improvement entails of a real exchange rate appreciation, while for the four others, it led to a depreciation. Feyzioglu ( 1997) found that a terms of trade improvement entailed a real exchange rate appreciation in Finland.

Consequently, the real exchange rate response to a positive shock on the terms of the trade crucially depends on the relative response of the nominal exchange rate to a variation of the domestic price of imports and thus the sign of the terms of trade coed cient is a priori unde..ned.

\subsubsection{A tarix decrease}

A decrease in $i$ decreases the domestic price of importable goods. This leads to an increase in the nominal exchange rate, $E$, and hence the relative prices of exportable goods with respect to non-tradable ones, ex. Then, the relative prices of importable goods with respect to non-tradable ones, $e_{M}$, must decrease to restore the internal equilibrium. The adjustment in the internal and external sect ors is exactly the same as in the case of a terms of trade improvement.

From (7), it follows that :

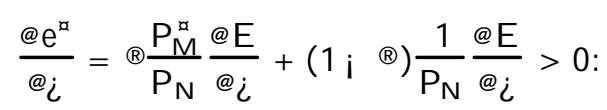

Faso, B axes and al (1999) found results in accordance with the theory : the 
exorts of trade liberalization in several developing countries came along with a real exchange rate depreciation.

\subsubsection{A n Increase in foreign assets and capital fows}

A $n$ increases in the interest earnings on the foreign assets of the country (if the country is a net creditor, that is, A $>0$ ) and an increase in the net capital ‡ow of the country have the same exect on the equilibrium exchange rate. An exogenous rise in $r^{x} A$ (assuming $A>0$ ) or $K I$ (in absolute value) leads to a short-run improvement in the balance of payment account. Since the net change of the o $\$$ cial reserves must be zero in equilibrium, the current account de..cit is expected to rise.

So, the equilibrium in the external sector implies a higher trade de..cit and this is only possible with a change in the nominal exchange rate and/ or nontradable prices. However, if only one of them adjusts the internal equilibrium cannot be attained, since we assume that the functional forms of $Q_{N}$ and $C_{N}$ are such that for each $E$ there exists a unique level of $P N$.

O ne can show that starting from an equilibrium situation, the only possible adjustment in $\mathrm{PN}$ and $\mathrm{E}$, in response to an increase in foreign assets or net capital łows, can be a simultaneous decrease. Furthermore, the decrease in $E$ must be relatively higher than that in $\mathrm{PN}$ so that ex must decrease, too. $\mathrm{O} n$ the other hand, en rises. Therefore, the output of exportable goods, $Q_{N}$ increases while consumption and hence the expenditure on importable goods decreases. As a result, trade surplus decreases and the equilibrium in the external sector is restored.

On the other hand, the consumption of non-tradable goods increase at a higher $e_{M}$ and a lower $P_{N}$. This increase is matched with an equal amount of increase in the output of non-tradable goods due to a lower level of $e_{X}$. So, the internal equilibrium is also restored.

De..ning $B$ as a variation of $r^{\ltimes} A$ or $K I$, one can write from (7) 


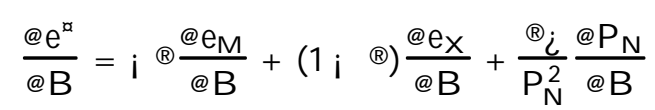

From (11) one can also write

$$
\frac{\mathbb{Q}_{N}}{\mathfrak{G B}}=\frac{\mathfrak{C C}_{N}}{\mathfrak{G B}}
$$

Combining these two equations and using $\Phi_{N}=\Phi<<$; $@ x=\infty<0$ and

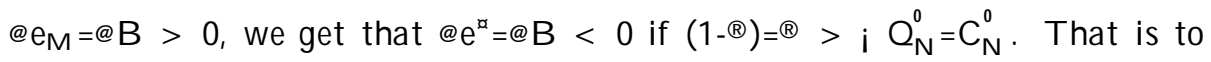
say, when ${ }^{\circledR}$ is suф ciently low, an increase in the earnings on net foreign assets or an increase in net capital łows leads to an equilibrium real exchange rate appreciation. If, on the other hand, the country is a net debtor a rise in the world real interest will result in a depreciation of the equilibrium real exchange rate.

\subsubsection{A public spending variation}

Public spending can also have an impact on the real exchange rate as it is extensive in tradable or non-tradable goods. We proceed as Edwards (1989) and we suppose a horizon of two periods. As a simpli..cation we ignore the tax distortion exect. If the State increases its spending in non-tradable goods in the ..rst period by ...nancing these additional spending by loans, the equilibrium real exchange rate will be axected in two ways. During the ..rst period, the demand increase entails a rise in the price of non-tradable goods and hence a real exchange rate appreciation. However, for the second period the State can increase taxes to pay for its debts, which reduces the available income and then demand fall $s^{1}$. This fall in demand leads to a decrease of the non-tradable goods price and hence to a real exchange rate depreciation. Thus, it is a priori hard to forecast the exect of a public spending variation on the equilibrium real exchange rate. The result will be the same if the State increases its spending in tradable goods.

\footnotetext{
${ }^{1}$ Exect is null if the Ricardienne equivalance is veri ..ed
} 
Edwards (1989) estimated six econometric models of real exchange rate determination for developing countries and found that for four of them, an increase of public spending entailed a real exchange rate appreciation. On the other hand, the two other models revealed that a public spending increase led to a real exchange rate depreciation.

\subsubsection{A n Increase in domestic investment share}

Here again the impact of an investment increase depends on its composition in tradable and non-tradable goods. If the increase of the investment rate entails a rise of the share of the non-tradable goods, there will be real a exchange rate appreciation (Edwards, 1989; Baxes and al, 1999). On the contrary, if the relative share of tradable goods go up, one will get a real exchange rate depreciation.

$B$ axes and al (1999) found that an increase of the investment rate led to a real exchange rate depreciation in the Ivory Coast. Edwards (1989) obtained the same result for a group of 12 developing countries.

\subsubsection{The I mpact of technical progress}

Ricardo was the ..rst to evoke a negative relation between economic growth (a proxy of technical progress) and the relative price of tradable goods with regard to non-tradable ones. Other authors also noted that the real exchange rate tends to appreciate with time (Balassa, 1964).

E dwards (1989) took technical progress into account in his model and showed that its exect on the real exchange rate both depended on its nature and on its exect in the various sectors of the economy. A positive productivity shock induces an income exect which entails an increase of the demand of non-tradable goods, which leads to a non-tradable price increase and hence a real exchange rate appreciation. However, technical progress can also induce a real exchange rate depreciation if the oxer exect which results from it, exceeds the demand exect. Edwards (1989) found that a technical progress increase led to a real exchange rate depreciation. On the other hand, A ron and al (1997) found that 
an increase of the technical progress level had entailed a real exchange rate appreciation in South A frica.

\section{The non-stationary dynamic panel economet- ric methodology}

B efore the development of econometric techniques adapted to non-stationary dynamic panels, previous studies on panel data implicitly supposed that the variables used were stationary. This constitutes a serious limitation to their results given the considerable bias existing in this case on the parameter estimates when the non-stationarity properties of data are not taken into account. D ue to the recent developments of econometrics, it is henceforth possible to test stationarity on panel data as well as the degree of integration of set of variables. We now present the panel unit root tests and panel cointegration tests that we will used in the empirical application reported in section 4.

\subsection{Panel unit root tests}

Initial methodological work on non-st ationary panels focused on testing unit roots in univariate panels. Quah (1994) derived standard normal asymptotic distributions for testing unit roots in homogeneous panels as both time series and cross sectional dimension grow large. Levin and Lin (1993) derived distributions under more general conditions that allow for heterogeneous ..xed exects and time trend. More recently, Im, Pesaran and Shin (1997), studied the small propert ies of unit root tests in panels with heterogeneous dynamics and proposed alternative tests based on the mean of individual unit-root statistics. In this paper we shall apply Im, Pesaran and Shin (1997) unit-root test (called IPS after) since it is more powerful than those of Quah (1994) and Levin and L in (1993) used in existing studies.

L evin and Lin's test is considered as more general than those of Quah since it explicitly takes heterogeneity and correlation between units into account. 
However as shown by Papell (1997) it suxers from size distortion without being able to correct serial cor relation ad equately. U sing M onte $C$ arlo simulations, he showed that the ..nite sample critical values are greater than those in Levin and $L$ in (1993). For quarterly data, the critical values are $11 \%$ higher (on average) than those reported by Levin and L in and for monthly data, they are $3 \%$ higher.

The test proposed by Im, Pesaran and Shin (1997) permits to solve L evin and Lin's serial correlation problem in assuming heterogeneity between units in a dynamic panel framework. Furthermore as shown by Im and al via Monte Carlo simulations it has higher power than that of Levin and Lin. IPS (1997) proposed two statistics : a Maximum Likelihood Statistics, called Lbar, and a Student statistic tb. These two statistics are based on individual A ugmented Dickey-Fuller (ADF) regressions. Since an appropriate ADF regression will correct the serial correlation in data, the IPF panel unit-root test takes care of serial correlation automatically. In our empirical work of section 4 we shall use the tb statistic instead of the Lbar one since IPS's Monte Carlo experiments have shown that it is the more powerful even for a value of $\mathrm{N}$ inferior to 5 . This statistic can be expressed as :

$$
t_{b}=\frac{p \bar{N}\left(t_{N T} ; E\left(t_{T}\right)\right.}{\overline{\operatorname{Var}\left(t_{T}\right)}}
$$

where $t_{N T}=\frac{1}{N}{ }_{i=1}^{\mathbb{P}} t_{i T}$ is an average of the $t$ individual student statistic in a conventional time series unit-root analysis, $E t_{T}$ and $V\left(t_{T}\right)$ are respectively the mean and variance of $t_{i T}$ under the null hypothesis that the series are integrated of order one with $\mathrm{N}$ ! 1 :

IPS show that under the null hypothesis of non-stationarity, the $t_{b}$ statistic follows the standard normal distribution asymptotically.

\subsection{Panel cointegration tests}

In the empirical application we shall apply Pedroni's cointegration test methodology (1995a, 1997 and 1999) to analyze the Balassa-Samuelson hypothesis. Pedroni (1995a) studied the properties of spurious regressions and tests 
for cointegration in heterogeneous panels and derived appropriate distributions for these cases. These allow us to test for the presence of long run equilibria in multivariate panels while permitting the dynamic and even the long run cointegrating vectors to be heterogeneous across individual members. Like the IPS panel unit-root test, the panel cointegration tests proposed by Pedroni also take heterogeneity into account using speci..c parameters which of course are allowed to vary across individual members of the sample. Pedroni (1997 and 1999) derived the asymptotic distributions and explored the small sample performances of seven dixerent statistics to test panel data cointegration. Of these seven statistics, four are based on pooling along, which is often referred to as the W ithin dimension (called "panel" after), and the last three are based on the Between dimension (called "group" after). These dixerent statistics are based on a model that assumes that cointegration relationships are heterogeneous between individual members and are de..ned as :

For the W ithin statistics

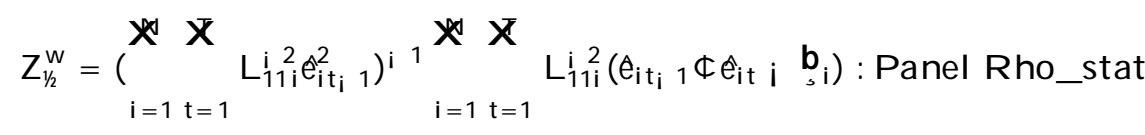

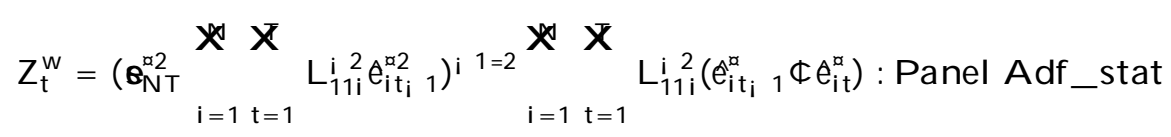

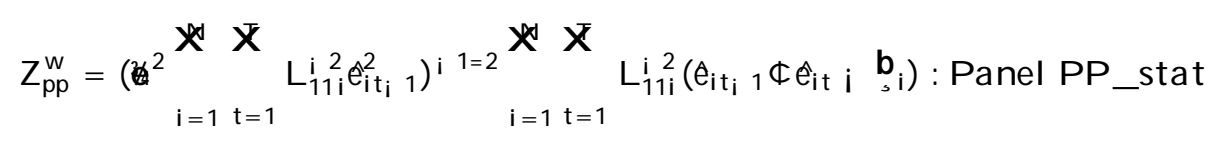

$$
\begin{aligned}
& Z_{v}^{w}=\left(X_{i=1}^{X_{t}^{N} X^{\top}} L_{11 i}^{i} \Theta_{t_{i} 1}^{2}\right)^{i}{ }^{1}: \text { Panel } V_{-} \text {stat }
\end{aligned}
$$

For the Between statistics

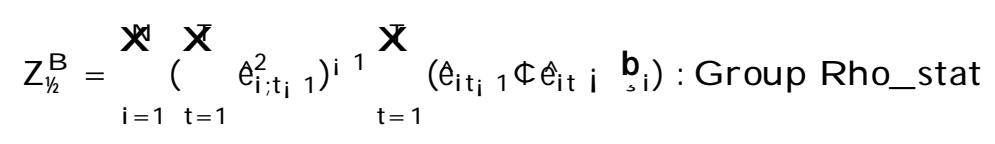




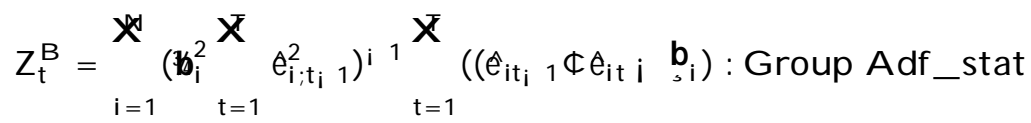

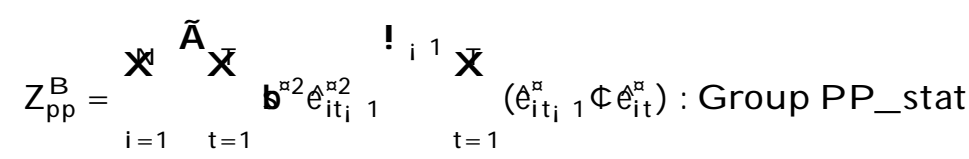

with,

$$
\begin{aligned}
& \mathrm{b}=\frac{1}{\mathrm{~T}}{ }_{\mathrm{s}=1}^{\mathbb{R}_{\mathrm{i}}}\left(1 \mathrm{i} \frac{\mathrm{s}}{\mathrm{k}_{\mathrm{i}}+1}\right)_{\mathrm{t}=\mathrm{s}+1}^{\mathrm{Pt}} \mathrm{b}_{\mathrm{it}} \mathrm{b}_{\mathrm{it}} \mathrm{s} \text {; } \\
& \mathbf{b}_{\mathrm{i}}^{2}=\frac{1}{T}{ }_{\mathrm{t}=\mathrm{s}+1}^{\mathrm{P}} \mathbf{b}_{\mathrm{it}}^{2} ; \boldsymbol{B}_{4}^{2}=\mathrm{s}_{\mathrm{i}}^{2}+2 \mathrm{~b}_{\mathrm{i}} \text {; } \\
& \Psi_{4}^{2}+2 b_{i} \text {; }
\end{aligned}
$$

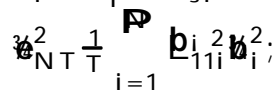

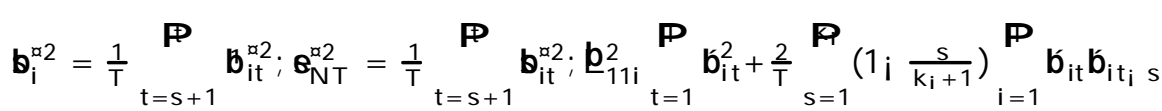

and where the residuals are extracted from the above regressions :

$$
\begin{aligned}
& a_{t}=B a_{t_{i} 1}+b_{i t} ; \\
& a_{t}=b a_{t_{i} 1}+{ }_{k=1}^{p_{i}} B_{i k} \phi a_{t_{i}}+b_{i t} ; \\
& \phi y_{i t}={ }_{m=1}^{P l} b_{m i} \phi X_{m i t}+b_{i t} ;
\end{aligned}
$$

Note that in the above writings $L_{i}$ represents the $i^{\text {th }}$ component of the Cholesky decomposition of the residual Variance-Covariance matrix,,$b$ and ${ }_{\mathrm{T}}^{2} \mathrm{~T}$ are two parameters used to adjust the autocorrelation in the model, 3/4 and $s_{i}^{2}$ are the contemporaneous and long-run individual variances.

Pedroni has shown that the asymptotic distribution of these seven statistics can be expressed as :

$$
\frac{\hat{A}_{N T ;{ }^{j}}{ }^{p} \bar{N}}{\bar{v}} ! N(0 ; 1)
$$

where $\hat{A}_{N T}$ is the statistic under consideration among the seven proposed, $N$ and $T$ are the sample parameter values and ${ }^{1}$ and $\varrho$ are parameters tabulated in Pedroni (1999). 
In terms of power Pedr oni (1997) showed that for values of $\mathrm{T}$ Iarger than 100, all the proposed seven statistics do fairly well and are quite stable. However for smaller samples ( $T$ inferior to 20 ) the Group ADF-Statistic (non-parametric) is the most powerful, followed by the $P$ anel V-Statistic and the $P$ anel rho-Statistic. For this reason, only the group ADF-statistic will be considered in our study for panel cointegration testing. The ..nite sample distribution for the seven statistics were tabulated by Pedroni (1997) via M onte C arlo simulations. T he calculated test st atistics must be larger (in absolute value) than the tabulated critical value to reject the null hypothesis of absence of cointegration.

\section{Empirical investigation of long term real ex- change rate determinants}

\subsection{The econometric relation to be tested and the data set}

The theor etical model developed in section 2 de..nes a long-run relationship between the real exchange rate and macroeconomic variables. The aim of this section is to test this relationship on panel data by taking explicitly the nonstationarity properties of the variables into account, and to identify the long term real exchange rate determinants.

Given the theoretical framework of section 2, the cointegrating relationship to be test ed between the real exchange rate and its fundamentals can be written as:

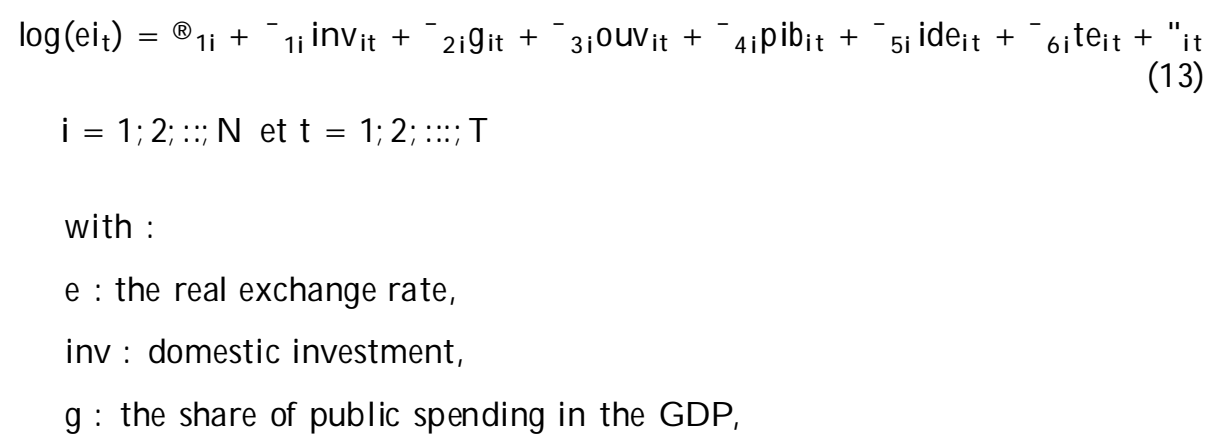




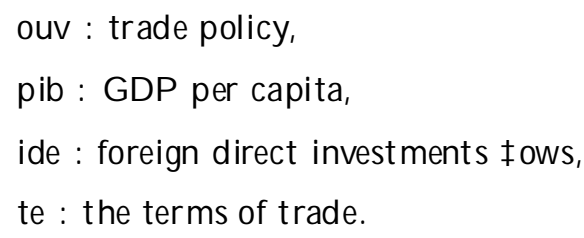

We consider a sample of 45 developing countries, divided into three groups according to geographical criteria: A frica (21 countries: A lgeria, Benin, B urkina Faso, Burundi, Cameroon, Congo, the democratic R epublic of $C$ ongo, Ivory Coast, Egypt, Ethiopia, Gabon, Gambia, Ghana, Guinea Bissau, Kenya, Mali, M orocco, Mozambique, Niger, Senegal, Tunisia), Latin A merica (17 countries: A rgentina, Bolivia, Brazil, Chile, Colombia, Costa Rica, Dominican Republic, Ecuador, Guatemala, Honduras, M exico, Nicaragua, Panama, Peru, Paraguay, Uruguay, Venezuela) and A sia ( 7 countries: Bangladesh, Indonesia, South K orea, India, Malaysia, the Philippines, Thailand).

The sample period is based on data availability and it covers 16 years for A frica (from 1980 to 1996), 23 years for Latin A merica (from 1973 to 1996) and 21 years for Asia (from 1975 to 1996). All the data are annual and are extracted from the world Bank data base for the fundamental and from the French database of the CEPII for the real exchange rate. The real exchange rate is de..ned with respect to the A merican dollar and an increase implies an appreciation.

The econometric methodology used is exposed in section 3. Let us indicate that the cointegration coed cients are estimated by the fully modi..ed least square method ( F mols), developed by Pedroni (1996). The advantage of this method with regard to the standard M CO is that it corrects distortions related to the correlation between regressors and residuals and that it is less sensitive to possible bias in small size samples (cf. Pedroni 2000).

Let us underline that the unavailability of data for some macroeconomic variables led us to proceed to some approximations. The ..rst one is related to public spending in non-tradable goods : as we cannot decompose them into tradable and non-tradable goods, we used the global public spending share in 
GDP as a proxy.

The second one concerns trade policy. Generally, in literature, the openness degree of the economy is approximated by the share of foreign trade in GDP. This approximation justi..es itself by the fact that ceteris paribus, a greater tradable liberalization allows to intensify trade and the convergence of prices. In our case we used the share of total imports in total domestic spending. Longrun capital movements are approximated by foreign direct net ‡ows (IDE). This choice justi..es itself by the fact that contrary to other ..nancial ¥ows, the IDE are related to output motivations and are therefore more stable.

The per capita income is used as a proxy to measure the wealth exect which is generated by technical progress. One expects the coec cient of the per capita income to be positive, given that an increase of the global demand following the wealth exect ends in an increase of the price of non-tradable goods and hence a real exchange rate appreciation.

\subsection{The econometric results and their economic interpre- tation}

The analysis ..rst step is simply to look at the data univariate properties and to determine their integrat edness degree. As indicated by the table in the appendix, panel data unit-root tests do not reject the unit-root null hypothesis. Furthermore, tests on the series in ..rst dixerences con..rm the hypothesis of stationarity. In other words, the real exchange rate and its potential determinants expressed in level are all integrated of order 1.

A fterwards, having con..rmed the non-stationarity of our series, it is natural to test the existence of a long-run relationship between the real exchange rate and its determinants. Table 1 reports the results of the panel data cointegration tests developed by Pedroni $(1997,1999,2000)^{2}$.

\footnotetext{
${ }^{2}$ Let us underline that at the chosen signi...cativity level, a cal culated statistic larger than the critical value will lead to reject the null hypothesis of absence of a cointegration relationship between the variables. Let us also indicate that ${ }^{-} \mathrm{j}$ represents the average of the estimated ${ }_{\text {ij }}$ for $\mathrm{j}$ varying from 1 to 6 (cf. equation 13).
} 
Table 1 : Equilibrium real exchange rate estimation

\begin{tabular}{|c|c|c|c|c|c|c|c|}
\hline & 1 & 2 & 3 & \multicolumn{2}{|c|}{${ }^{4}$ frica $^{5}$} & 6 & G roup-A D F-stat $\left(Z_{t}^{B}\right)$ \\
\hline Coes & 0.17 & -0.05 & -0.16 & 0.07 & 0.06 & 0.56 & \\
\hline t-stat & 3.04 & -2.92 & -2.38 & 3.62 & 2.76 & 8.58 & 5.91 \\
\hline \multicolumn{8}{|c|}{ L atin A merica } \\
\hline Coed & 0.17 & 0.10 & -0.09 & 0.23 & 0.02 & ns & \\
\hline t-stat & 3.04 & 2.43 & -2.97 & 3.35 & 3.21 & & 3.82 \\
\hline \multicolumn{8}{|c|}{ A sia } \\
\hline Coed & 0.37 & -0.13 & -0.39 & 0.39 & 0.07 & 0.53 & \\
\hline t-stat & 2.11 & -3.53 & -11.01 & 10.08 & 4.58 & 2.94 & 12.16 \\
\hline
\end{tabular}

Compared with the (1.65) critical value at the $5 \%$ level, the calculated statistics $Z_{t}^{B}$ of $P$ edroni's cointegration test clearly indicates the existence of a long-run relationship between the real exchange rate and its fundamentals for the three sets of countries. For these three groups the cointegration coet cients of the IDE con..rm the theoretical predictions. The estimated coed cient $\left({ }^{-}{ }_{5}\right)$ is positive, implying that a capital $\ddagger$ ow increase entails a domestic spending rise and a reallocation of output factors towards the non-tradable goods sector; the long-run demand increase of the non-tradable goods entails a real exchange rate appreciation. Furthermore, the coet cients are very close for the three groups of countries. Indeed, an increase of $1 \%$ of foreign investments $\ddagger$ ows leads to an average real exchange rate appreciation of $0.05 \%$.

The per capita GDP contributes to the long-run variations of the real exchange rate for the three groups of countries. Coec cient $\left({ }^{-}{ }_{4}\right)$ is positive, which implies that economic development is accompanied by a real exchange rate appreciation (B alassa-Samuelson exect). The exect of economic development on the long-run evolution of the real exchange rate is relatively low in A frica. Indeed, an increase of $1 \%$ of per capita GDP entails a real exchange rate appreciation of only $0.07 \%$. On the other hand, this exect is relatively high in A sia and Latin A merica because real exchange rate appreciates respectively of 0.39 $\%$ and $0.23 \%$ for these countries following an increase of $1 \%$ of the per capita GDP. 
The exect of public spending on real exchange rates of $\left({ }^{-}{ }_{2}\right)$ is dixerent for the three groups of countries. Indeed, estimations indicate that an increase of public spending entails a real exchange rate appreciation in Latin A merica and a depreciation in A sia and A frica. According to the theor etical predictions the coed cient must be positive given that the increase of the global demand of the non-tradable goods entails an increase of their price. The negative coec cient in A sia and A frica can refect a strong eviction exect which induces a fall in private non-tradable goods demand. If public spending is extensive in tradable goods, an expansionist budget policy entails a tax increase or/ and an inter est rate rise, which reduces the private demand of non-tradable goods. The fall in demand then entails a price decrease and hence a real exchange rate depreciation (cf. Edwards, 1989). The exect of public spending on the real exchange rate in $L$ atin A merica and in A sia is comparable and relatively higher than in A frica.

E mpirical results con..rm that an improvement of the terms of trade entails a real exchange rate appreciation in A frica and in Asia, which means that the weal th exect dominates the income exect. Furthermore, the elasticity of the real exchange rate with respect to the terms of trade is compatible with previous studies. The dixerence between the economic structures of the two groups of countries partially explains the dixerence of response of real exchange rates to a shock on the terms of trade (an improvement of $10 \%$ of the terms of trade entails an ap preciation of $5.3 \%$ in A frica and $5.6 \%$ in A sia). The absence of the exect of the terms of trade on the real exchange rate in L atin A merica con..rms that the wealth exect compensates for the substitution exect.

Negative coec cients $\left({ }^{-}{ }_{3}\right)$ for the three groups of countries suggest that trade liberalization is accompanied with a real exchange rate depreciation. The elasticity is dixerent for the three groups of countries: it is of -0.16 in A frica, of -0.39 in A sia and of -0.09 in L atin A merica. Nevertheless, this elasticity remains relatively low for these countries in comparison to the previous results of liter ature (Elbadawi and Soto, 1995; Baxes and al, 1999). A possible explanation is that the estimated coed cients are averages of individual coec cients.

Finally, an increase of $10 \%$ on the share of domestic investments entails an 
average depreciation of $1.7 \%$ in Africa and in Latin A merica and of $3.7 \%$ in A sia. This result is compatible with that of Edwards (1989) which also found a low elasticity (of $7 \%$ ) for a group of 12 developing countries. Indeed, an increase of investments often leads to an increase of non-tradable goods spending and hence to a decrease of the relative price of non-tradable goods.

F inally, let us notice that in A frica and in A sia external factors (openness degree and terms of trade) contribute most to the long-run dynamics of the real exchange rate; internal demand also plays an important role in A sia. In Lat in A merica on the other hand, external factors seem to have a relatively limited exect on equilibrium real exchange rate, the economic development (GDP per capita) having on the contrary an import ant role.

\section{Conclusion}

The aim of this paper was to identify the determinants of the equilibrium real exchange rate, others than the Balassa-Samuel son exect. O $n$ the basis of theoretical approaches generally used in literature, we have exposed a simple theor etical model which describes the interaction between some macr oeconomic variables and the equilibrium real exchange rate level. Then, this model has been estimated by recent non-stationary dynamic panel techniques. We have in particular used the panel data integration tests recently proposed by Im, Pesaran and Shin (1997) as well as the panel data co-integration tests developed by Pedroni (1997, 1999, 2000), which has enabled us to put in evidence the existence of several sources of impulsions in uencing the real exchange rate in the long-term.

O ur investigations show that an improvement of the terms of trade, an increase of per capita GDP and of capital łows entail a long-run ap preciation of the real exchange rate. On the other hand, an increase of the domestic investment and of the openness degree of the economy entails a real exchange rate depreciation; the exect of public spending increase being ambiguous.

O ur investigations con..rm that having a reference to assess the degree of 
distortion of the real exchange rate is not as simple as it can be thought with the PPP concept. The real exchange rate is exectively at the centre of an economic spiral and its value depends on the economic speci..cities of each country. In other words, we don't have a ..xed and general norm but, for each economy, the real exchange rate trajectory depends on its development level, on the way economic policy is conducted, and on its position on the international market. Besides, the variations of the real exchange rate do not necessarily rełect a disequilibrium. Indeed, equilibrium adjustments related to fundamental variations can also generate real exchange rate movements. 


\section{R eferences}

[1] A glietta M., Baulant C., Coudert V. (1997), "W hy the euro will be strong : an approach based on equilibrium exchange rates", Document de travail du CEPII, $\mathrm{n}^{ \pm} 97-18,31 \mathrm{p}$.

[2] A ron, J ., Elbadawi, I., and K ahn, B. (1997), "Determinants of the Real Exchange R ate in South A frica," Center for the Study of A xrican Economies, WPS/97-16, CSAE Publishing, Oxford.

[3] Baxes J., I. Elbadawi and S. O'Conelle (1999), "Single-Equation of the Equilibrium Real Exchange Rate," in Hankle L . and P M entiel, Exchange rate and measurement for developing countries, Oxford University Press, pp 405-64.

[4] Balassa B. (1964), "The Purchasing Power Parity Doctrine : A Reappraisal," J ournal of political Economy, Vol. 72, pp 584-96.

[5] Clark P. and R. Mac Donald (1998), "Exchange R ate and E conomic Fundamentals: A M ethodological Comparaison of BEERs and FEERSs," IMF Working Paper, $n^{ \pm}$W P/ 98/ 67.

[6] Cottani, J .A ., Cavallo, F. and K han Shahbaz (1990); "R eal Exchange Rate Behavior and Economic Performance in LDCS," Economic Development and Cultural Change, Vol.39, pp 61-76.

[7] Drine, I. and Rault C. (2003a), "Do Panel Data permit to rescue the Balassa-Samuleson hypothesis for Latin American countries ?", Applied Economics, vol 35, $n \pm 3$, pp 351-361.

[8] Edwards S. (1988), "Real and M onetary Determinants of Real Exchange Rate Behavioral," J ournal of Development E conomics, Vol. 29, pp 311-341.

[9] Edwards S., ( 1989) Real Exchange Rates, Devaluation and Adjustment : Exchange Rate Policy in Developing Countries, Cambridge, Mass: MIT Press. 
[10] Égert B., Drine I., Lommatzsch K., Rault C. (2003b), "The BalassaSamuelson exect in Central and Eastern Europe: Myth or reality ?", William Davidson Institute W or king Paper Series, 2002, $n^{ \pm} 483$, University of M ichigan Business School, USA. Forthcoming in J ournal of Comparative E conomics in September.

[11] Elbadawi I and R. Soto (1995), "C apital Flows and Equilibrium Real Exchange $\mathrm{R}$ ate in Chile," Policy Research W orking Paper 1306, Banque mondiale, Washington DC.

[12] Faruquee H., (1995), "Long-run determinants of the real exchange rate", IM F Staœ Papers, vol. 42, $n^{ \pm} 1$, March, pp. 80-107.

[13] Feyzioglu T. (1997), “Estimating the Equilibrium Real Exchange Rate : An A pplication to Finland," IMF W orking Paper, N WP/ 97/ 109.

[14] Ghura, D. and T. Grennes (1993), "T he Real Exchange R ate and M acroeconomic Performance in Sub-Saharan Africa," J ournal of Development E conomics, Vol. 42, pp. 155-174.

[15] Im K., Pesaran H., Shin Y . (1997), "Testing for unit roots in heterogeneous panels", Discussion Paper, University of Cambridge, J une.

[16] Levin and L in (1993), "U nit root tests in panel data, asymptotic and ..nite sample properties", U.C. San Diego W orking paper.

[17] M ac D onald R . (1997), "W hat determines real exchange rates? The long and short of it", IMF Staa Papers, W P/ 97/ 21, pp. 53.

[18] Pedroni, P. (1996), "Fully modi..ed OLS for heterogeneous cointegrated panel s and the case of Purchasing P ower Parity", Indiana U niver si ty W orking $P$ aper in E conomics, no. 96-020. June.

[19] Pedroni, P.(1997), "Panel cointegration : asymptotic and ..nite sample properties of pooled time series tests with an application to the PPP hypothesis: New results", Indiana University Working Paper in E conomics, A pril. 
[20] Pedroni, P. (1999), "Critical values for cointegrating tests in heterogeneous panels with multiple regressors", O xford Bulletin of Economics and Statistics.

[21] Pedroni, P. (2000) "Fully Modi..ed OLS for Heterogeneous Cointegrated Panels," Advances in Econometrics, Vol. 15, forthcoming.

[22] Quah D. (1994), "Exploiting Cross Section variations for unit root inference in dynamic data", Economics Letters, $\mathrm{n} \pm 44$, pp 9-19.

[23] Stein J . (1994), "T he N atural R eal exchange R ate of the US D ollar and the determinants of capital łows ", in : W illiamson J. (ed.), Estimating equilibrium exchange rate, Institute for International Economics, Washingt on D.C., September, pp.133-76.

[24] Stein J . and P. A llen ( 1995), Fundamental D eter minants of Exchange Rates, Oxford Clarendon Press.

[25] Williamson J . (1983), The Open Economy and the W orld economy, New York, B asic Books.

[26] Williamson J (1994), Estimating Equilibrium exchange rate, Institute for International E conomics, Washington, DC. 


\section{Appendix : \\ Panel unit-root test results (Im, Pesaran and Shin, 1997) for Africa, Latin America and Asia}

\section{1) Africa}

\begin{tabular}{|c|c|c|c|c|}
\hline \multicolumn{5}{|c|}{ Real exchange rate } \\
\hline & Level & \multicolumn{3}{|c|}{ First difference } \\
\hline & Constant & Constant and trend & Constant & Constant and trend \\
\hline & $-1.34^{1}$ & $1.7^{2}$ & -2.30 & 2.38 \\
\hline \multicolumn{5}{|l|}{ GDP per capita } \\
\hline & Level & \multicolumn{3}{|c|}{ First difference } \\
\hline & Constant & Constant and trend & Constant & Constant and trend \\
\hline & -0.09 & 1,70 & -2.30 & 2.38 \\
\hline \multicolumn{5}{|l|}{ Terms of trade } \\
\hline & Level & \multicolumn{3}{|c|}{ First difference } \\
\hline & Constant & Constant and trend & Constant & Constant and trend \\
\hline & -0.66 & 0.17 & -7.77 & -5.72 \\
\hline \multicolumn{5}{|l|}{ Openness degree } \\
\hline & Level & \multicolumn{3}{|c|}{ First difference } \\
\hline & Constant & Constant and trend & Constant & Constant and trend \\
\hline & -0.55 & 0.063 & -2.33 & -7.77 \\
\hline \multicolumn{5}{|l|}{ Public spending } \\
\hline & Level & \multicolumn{3}{|c|}{ First difference } \\
\hline & Constant & Constant and trend & Constant & Constant and trend \\
\hline & -0.79 & -1.79 & -3.45 & -4.05 \\
\hline \multicolumn{5}{|l|}{$\begin{array}{l}\text { Foreign direct } \\
\text { investments }\end{array}$} \\
\hline & Level & \multicolumn{3}{|c|}{ First difference } \\
\hline & Constant & Constant and trend & Constant & Constant and trend \\
\hline & -0.19 & -1.62 & -2.63 & -4.35 \\
\hline \multicolumn{5}{|l|}{ Domestic investments } \\
\hline & Level & \multicolumn{3}{|c|}{ First difference } \\
\hline & Constant & Constant and trend & Constant & Constant and trend \\
\hline & -0.23 & -1.14 & -3.89 & -3.23 \\
\hline
\end{tabular}

\section{2) Latin America}

\begin{tabular}{|c|c|c|c|c|}
\hline \multicolumn{5}{|c|}{ Real exchange rate } \\
\hline & Level & \multicolumn{3}{|c|}{ First difference } \\
\hline & Constant & Constant and trend & Constant & Constant and trend \\
\hline & -0.23 & 1.43 & -3.32 & 4.32 \\
\hline \multicolumn{5}{|l|}{ GDP per capita } \\
\hline & Level & \multicolumn{3}{|c|}{ First difference } \\
\hline & Constant & Constant and trend & Constant & Constant and trend \\
\hline
\end{tabular}

\footnotetext{
${ }^{1}$ The critical value is of -1.65 .

${ }^{2}$ The critical value is of -1.65 .
} 


\begin{tabular}{|c|c|c|c|c|}
\hline & -0.12 & 1,43 & -2.21 & 2.54 \\
\hline \multicolumn{5}{|l|}{ Terms of trade } \\
\hline & Level & \multicolumn{3}{|c|}{ First difference } \\
\hline & Constant & Constant and trend & Constant & Constant and trend \\
\hline & -0.32 & 0.43 & -5.45 & -5.21 \\
\hline \multicolumn{5}{|l|}{ Openness degree } \\
\hline & Level & \multicolumn{3}{|c|}{ First difference } \\
\hline & Constant & Constant and trend & Constant & Constant and trend \\
\hline & -0.43 & 0.98 & -3.23 & -6.47 \\
\hline \multicolumn{5}{|l|}{ Public spending } \\
\hline & Level & \multicolumn{3}{|c|}{ First difference } \\
\hline & Constant & Constant and trend & Constant & Constant and trend \\
\hline & -1.32 & -1.12 & -2.31 & -3.21 \\
\hline \multicolumn{5}{|l|}{$\begin{array}{l}\text { Foreign direct } \\
\text { investments }\end{array}$} \\
\hline & Level & \multicolumn{3}{|c|}{ First difference } \\
\hline & Constant & Constant and trend & Constant & Constant and trend \\
\hline & -0.12 & -1.43 & -2.12 & -5.22 \\
\hline \multicolumn{5}{|l|}{ Domestic investments } \\
\hline & Level & \multicolumn{3}{|c|}{ First difference } \\
\hline & Constant & Constant and trend & Constant & Constant and trend \\
\hline & -0.41 & -1.21 & -3.32 & -4.23 \\
\hline
\end{tabular}

\section{3) Asia}

\begin{tabular}{|c|c|c|c|c|}
\hline \multicolumn{5}{|c|}{ Real exchange rate } \\
\hline & Level & \multicolumn{3}{|c|}{ First difference } \\
\hline & Constant & Constant and trend & Constant & Constant and trend \\
\hline & -0.32 & 1.67 & -2.54 & 2.12 \\
\hline \multicolumn{5}{|l|}{ GDP per capita } \\
\hline & Level & \multicolumn{3}{|c|}{ First difference } \\
\hline & Constant & Constant and trend & Constant & Constant and trend \\
\hline & -0.19 & 1,45 & 2.31 & 3.45 \\
\hline \multicolumn{5}{|l|}{ 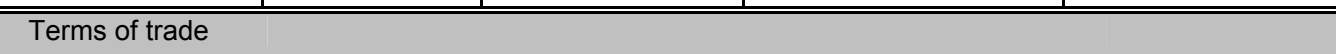 } \\
\hline & Level & \multicolumn{3}{|c|}{ First difference } \\
\hline & Constant & Constant and trend & Constant & Constant and trend \\
\hline & -0.36 & 0.32 & -5.47 & -6.32 \\
\hline \multicolumn{5}{|l|}{ Openness degree } \\
\hline & Level & \multicolumn{3}{|c|}{ First difference } \\
\hline & Constant & Constant and trend & Constant & Constant and trend \\
\hline & -0.12 & 0.43 & -2.54 & -3.34 \\
\hline \multicolumn{5}{|l|}{ Public spending } \\
\hline & Level & \multicolumn{3}{|c|}{ First difference } \\
\hline & Constant & Constant and trend & Constant & Constant and trend \\
\hline & -0.86 & -1.68 & -3.32 & -4.65 \\
\hline \multicolumn{5}{|l|}{$\begin{array}{l}\text { Foreign direct } \\
\text { investments }\end{array}$} \\
\hline & Level & \multicolumn{3}{|c|}{ First difference } \\
\hline & Constant & Constant and trend & Constant & Constant and trend \\
\hline
\end{tabular}


William Davidson Institute Working Paper 571

\begin{tabular}{|c|c|c|c|c|}
\hline & -0.21 & $\begin{array}{l}-1.42 \\
\end{array}$ & -2.55 & -3.21 \\
\hline \multicolumn{5}{|l|}{ Domestic investments } \\
\hline & Level & & irst differenc & \\
\hline & Constant & Constant and trend & Constant & Constant and trend \\
\hline & -1.32 & -1.35 & -3.21 & -4.67 \\
\hline
\end{tabular}




\section{DAVIDSON INSTITUTE WORKING PAPER SERIES - Most Recent Papers}

The entire Working Paper Series may be downloaded free of charge at: www.wdi.bus.umich.edu

CURRENT AS OF 5/6/03

\begin{tabular}{|c|c|c|}
\hline Publication & Authors & Date \\
\hline $\begin{array}{l}\text { No. 571: On the long-run determinants of real exchange rates for } \\
\text { developing countries: Evidence from Africa, Latin America and Asia }\end{array}$ & Imed Drine and Christophe Rault & May 2003 \\
\hline $\begin{array}{l}\text { No. 570: A re-examination of the Purchasing Power Parity using non- } \\
\text { stationary dynamic panel methods: a comparative approach for } \\
\text { developing and developed countries }\end{array}$ & Imed Drine and Christophe Rault & May 2003 \\
\hline $\begin{array}{l}\text { No. 569: How Important is Ownership in a Market with Level Playing } \\
\text { Field? The Indian Banking Sector Revisited }\end{array}$ & $\begin{array}{l}\text { Sumon Kumar Bhaumik and } \\
\text { Ralitza Dimova }\end{array}$ & May 2003 \\
\hline $\begin{array}{l}\text { No. 568: On Types of Trade, Adjustment of Labor and Welfare Gains } \\
\text { During Asymmetric Liberalizations }\end{array}$ & Yener Kandogan & May 2003 \\
\hline $\begin{array}{l}\text { No. 567: Technological Progress Through Trade Liberalization in } \\
\text { Transition Countries }\end{array}$ & Yener Kandogan & May 2003 \\
\hline $\begin{array}{l}\text { No. 566: Intra-industry Trade of Transition Countries: Trends and } \\
\text { Determinants }\end{array}$ & Yener Kandogan & May 2003 \\
\hline $\begin{array}{l}\text { No. 565: Local Protectionism and Regional Specialization: Evidence } \\
\text { from China's Industries }\end{array}$ & $\begin{array}{l}\text { Chong-En Bai, Yingjuan Du, } \\
\text { Zhigang Tao, Sarah Y. Tong }\end{array}$ & May 2003 \\
\hline No. 564: Corporate Governance and Market Valuation in China & $\begin{array}{l}\text { Chong-En Bai, Qiao Liu, Joe Lu, } \\
\text { Frank M. Song, and Junxi Zhang }\end{array}$ & May 2003 \\
\hline $\begin{array}{l}\text { No. 563: Revenue Sharing and Control Rights in Team Production: } \\
\text { Theories and Evidence From Joint Ventures }\end{array}$ & $\begin{array}{l}\text { Chong-En Bai, Zhigang Tao, and } \\
\text { Changqi Wu }\end{array}$ & May 2003 \\
\hline $\begin{array}{l}\text { No. 562: Financial Dependence, Stock Market Liberalizations and } \\
\text { Growth }\end{array}$ & Nandini Gupta and Kathy Yuan & May 2003 \\
\hline $\begin{array}{l}\text { No. 561: Growth and Regional Inequality in China During the Reform } \\
\text { Era }\end{array}$ & Derek Jones, Cheng Li and Owen & May 2003 \\
\hline $\begin{array}{l}\text { No. 560: Choice of Ownership Structure and Firm Performance: } \\
\text { Evidence from Estonia }\end{array}$ & $\begin{array}{l}\text { Derek Jones, Panu Kalmi, Niels } \\
\text { Mygind }\end{array}$ & May 2003 \\
\hline No. 559: Explaining Postcommunist Economic Performance & Lawrence P. King & May 2003 \\
\hline $\begin{array}{l}\text { No. 558: Tax Structure and the FDI: The Deterrent Effects of } \\
\text { Complexity and Uncertainty }\end{array}$ & $\begin{array}{l}\text { Kelly Edmiston, Shannon Mudd } \\
\text { and Neven Valev }\end{array}$ & Apr. 2003 \\
\hline No. 557: Provincial Protectionism & Konstantin Sonin & Apr. 2003 \\
\hline $\begin{array}{l}\text { No. 556: Nominal and Real Convergence in Estonia: The Balassa- } \\
\text { Samuelson (dis)connection }\end{array}$ & Balázs Égert & Apr. 2003 \\
\hline $\begin{array}{l}\text { No. 555: Banks-Firms Nexus under the Currency Board: Empirical } \\
\text { Evidence from Bulgaria }\end{array}$ & $\begin{array}{l}\text { Nikolay Nenovsky, Evgeni Peev } \\
\text { and Todor Yalamov }\end{array}$ & Apr. 2003 \\
\hline $\begin{array}{l}\text { No. 554: To Steal or Not to Steal: Firm Attributes, Legal Environment, } \\
\text { and Valuation }\end{array}$ & Art Durnev and E. Han Kim & Apr. 2003 \\
\hline No. 553: Corporate Stability and Economic Growth & $\begin{array}{l}\text { Kathy S. He, Randall Morck and } \\
\text { Bernard Yeung }\end{array}$ & Apr. 2003 \\
\hline $\begin{array}{l}\text { No. 552: So Many Rocket Scientists, So Few Marketing Clerks: } \\
\text { Occupational Mobility in Times of Rapid Technological Change }\end{array}$ & $\begin{array}{l}\text { Nauro F. Campos and Aurelijus } \\
\text { Dabušinskas }\end{array}$ & Mar. 2003 \\
\hline $\begin{array}{l}\text { No. 551: Determinants of Interregional Mobility in Russia: Evidence } \\
\text { from Panel Data }\end{array}$ & $\begin{array}{l}\text { Yuri Andrienko and Sergei } \\
\text { Guriev }\end{array}$ & Feb. 2003 \\
\hline $\begin{array}{l}\text { No. 550: Gross Job Flows in Ukraine: Size, Ownership and Trade } \\
\text { Effects }\end{array}$ & $\begin{array}{l}\text { Jozef Konings, Olga Kupets and } \\
\text { Hartmut Lehmann }\end{array}$ & Mar. 2003 \\
\hline $\begin{array}{l}\text { No. 549: Technology Transfer through FDI in Top-10 Transition } \\
\text { Countries: How Important are Direct Effects, Horizontal and Vertical } \\
\text { Spillovers? }\end{array}$ & $\begin{array}{l}\text { Jože P. Damijan, Mark Knell, } \\
\text { Boris Majcen and Matija Rojec }\end{array}$ & Feb. 2003 \\
\hline $\begin{array}{l}\text { No. 548: Does Foreign Direct Investment Increase the Productivity of } \\
\text { Domestic Firms? In Search of Spillovers through Backward Linkages }\end{array}$ & Beata K. Smarzynska & Mar. 2003 \\
\hline $\begin{array}{l}\text { No. 547: Re-employment Probabilities and Wage Offer Function for } \\
\text { Russian Labor Market }\end{array}$ & Natalia V. Smirnova & Feb. 2003 \\
\hline $\begin{array}{l}\text { No. 546: Democratization's Risk Premium: Partisan and Opportunistic } \\
\text { Political Business Cycle Effects on Sovereign Ratings in Developing } \\
\text { Countries }\end{array}$ & $\begin{array}{l}\text { Steven Block, Burkhard N. } \\
\text { Schrage and Paul M. Vaaler }\end{array}$ & Feb. 2003 \\
\hline
\end{tabular}

